BRONIStAW GÓRZ

Podhalańska Państwowa Wyższa Szkoła Zawodowa, Nowy Targ, Polska - Podhale State College of Applied Sciences in Nowy Targ, Poland

AgNIESZKA GIL

Uniwersytet Pedagogiczny w Krakowie, Polska - Pedagogical University of Cracow, Poland

Marcin SemcZuk

Uniwersytet Ekonomiczny w Krakowie, Polska - Cracow University of Economics, Poland

\title{
Szanse i ograniczenia w realizacji programów rewitalizacji obszarów wiejskich województwa małopolskiego
}

\section{Opportunities and Constraints in the Implementation of Revitalisation Programmes of Rural Areas in the Małopolskie Voivodeship}

\begin{abstract}
Streszczenie: Przedmiotem prezentowanych rozważań są programy rewitalizacji zgłoszone do realizacji przez gminne jednostki samorządu terytorialnego (JST) w województwie małopolskim w latach 2015-2016. Za cel opracowania przyjęto ocenę założeń rewitalizacji oraz określenia możliwości ich realizacji w kontekście pozostających od dawna do rozwiązania problemów społeczno-ekonomicznych obszarów wiejskich w poszczególnych rejonach województwa małopolskiego. Ponadto w opracowaniu skupiono się na ukazaniu potrzeb społeczno-ekonomicznych małopolskich wsi, ich dużego zróżnicowania $\mathrm{w}$ przestrzeni regionu oraz na omówieniu różnych ograniczeń, które mogą osłabiać skuteczność wdrażanych programów rewitalizacyjnych. Cel pracy zrealizowano dzięki analizie dokumentów będących podstawą wdrażania programów rewitalizacyjnych, przedstawieniu zróżnicowania rozwoju społeczno-gospodarczego gmin wiejskich na podstawie analizy wskaźnikowej oraz dokonania typologii obszarów wiejskich regionu. Kluczową kwestią dla znacznej części małopolskich wsi pozostaje ich niska efektywność ekonomiczna, wynikająca z dużego bezrobocia rejestrowanego i ukrytego, z niskiej aktywności mieszkańców w sferze pozarolniczej czy też z malejącej efektywności gospodarowania gruntami. Wiele obszarów cechuje postępujące wykluczanie z rozwoju i brak zdolności do wykorzystania posiadanych zasobów jako podstawy dobrej gospodarki lokalnej. W pracy dużo uwagi poświęcono uwarunkowaniom skuteczności programu rewitalizacji w rozwiązywaniu problemów wsi, które, w przekonaniu autorów, wiążą się głównie z pozyskaniem przy jego realizacji szerokiego poparcia mieszkańców, lokalnych przedsiębiorców i zaangażowania władz samorządowych, a następnie z odpowiednim wsparciem poszczególnych gmin przez działania szczebla regionalnego, a także z większą elastycznością tych programów, tak w odniesieniu do celu rewitalizacji, jak i do lokalizacji zadań $\mathrm{w}$ przestrzeni gminy. Działania związane z tym programem powinny znacznie poprawić te właśnie sfery potrzeb mieszkańców. Powinny też ograniczyć istniejącą peryferyjność wielu wsi widoczną w dużym oddaleniu i trudnym dostępie nie tylko do większych ośrodków społeczno-gospodarczych, ale także do upowszechnianych dzisiaj sposobów pozyskiwania informacji, kontaktu z kulturą, wiedzą, służących budowaniu silnych więzi społecznych i rozwojowi cywilizacyjnemu.
\end{abstract}

Abstract: The subject of the present article are revitalisation programmes submitted for implementation by municipal territorial self-government units in Małopolskie voivodeship in the years 2015-2016. 
The aim of the paper is the assessment of revitalisation assumptions and definition of their implementation possibilities in the context of ever-present socio-economic problems of rural areas in particular regions of Małopolskie voivodeship. In addition, the paper concentrates on showing the socio-economic needs of villages of Małopolskie voivodeship and their wide diversity in the region, discussing various constraints that may weaken the effectiveness of the revitalisation programs under implementation. The aim of the paper was accomplished through the analysis of the documents that constitute the basis for the implementation of revitalisation programmes, and the presentation of the diversity of socio-economic development of rural municipalities using ratio analysis, as well as carrying out the typology of rural areas of the region. The key issue of a large part of villages of Małopolskie voivodeship is their low economic efficiency resulting from high registered and hidden unemployment, low non-agricultural activity of residents, or decreasing land-use efficiency. Many areas are characterised by progressive exclusion from development and inability to use their resources as a basis for good local economy. Much attention has been paid to the effectiveness of the revitalisation programme in resolving rural problems which, in the authors' opinion, is mainly related to obtaining broad support from the residents and local entrepreneurs, local self-government involvement, followed by adequate support from the municipalities through actions at the regional level, as well as greater flexibility of these programmes, both with regard to the aim of revitalisation and the location of tasks within the municipality. Actions related to this programme should significantly improve these areas of needs of residents. They should also limit the existing peripherality of many villages, visible in remoteness and difficult access not only to larger socio-economic centers but also to today's information gathering methods, and contact with culture and knowledge, necessary for building strong social ties and civilisation development.

Słowa kluczowe: obszary wiejskie; odnowa wsi; przedsiębiorcza wieś; rewitalizacja; województwo małopolskie

Keywords: entrepreneurship in the countryside; Małopolskie voivodeship; revitalisation; rural areas; rural renewal programme

Otrzymano: 30 listopada 2017

Received: 30 November 2017

Zaakceptowano: 19 czerwca 2018

Accepted: 19 June 2018

\section{Sugerowana cytacja/Suggested citation:}

Górz, B., Gil, A., Semczuk, M. (2018). Szanse i ograniczenia w realizacji programów rewitalizacji obszarów wiejskich województwa małopolskiego. Przedsiębiorczość - Edukacja [Entrepreneurship Education], 14, 93-108. DOI: 10.24917/20833296.14.7

\section{Wstęp}

Obecna perspektywa finansowa związana $\mathrm{z}$ wykorzystaniem funduszy europejskich wspomagających rozwój wsi została zdefiniowana jako rewitalizacja, ale jej podstawowe cele są powiązane z poprzednimi działaniami na rzecz obszarów wiejskich. Ma bowiem służyć podniesieniu poziomu życia mieszkańców, poprawić konkurencyjność tych obszarów i wzmocnić spójność przestrzenną regionu. Różni się jednak od wcześniejszych programów, jak na to wskazują dostępne dokumenty, tym, że wskazuje nieco inne sposoby osiągnięcia założonych celów. Akcentuje silniej niż poprzednie działania współudział w programach rewitalizacji społeczności i partnerów lokalnych. Mają oni współuczestniczyć $\mathrm{w}$ realizowanych projektach przy założeniu, że projekty te będą identyfikowane w przestrzeni miejscowości ich zamieszkania (w określonej części wsi lub miasta). 
W założeniach programowych rewitalizacji podkreślane są ważne zadania gospodarcze, które nie tylko podniosą ekonomiczny standard życia ludności, ale też w większym niż dotąd stopniu poprawią możliwości korzystania przez mieszkańców z instytucji kultury, ułatwią zdobywanie wiedzy czy umożliwią szerszy dostęp do informacji. Mieszkańcy wsi mają identyfikować się z działaniami władz samorządowych na rzecz poprawy atrakcyjności swoich miejsc zamieszkania i realizacji celów życiowych.

Przedmiotem prezentowanych rozważań są programy rewitalizacji zgłoszone do realizacji przez gminne jednostki samorządu terytorialnego w województwie małopolskim w perspektywie finansowej 2014-2020. Za cel opracowania przyjęto ocenę celów rewitalizacji oraz określenie możliwości ich realizacji w kontekście pozostających od dawna do rozwiązania problemów społeczno-ekonomicznych obszarów wiejskich w poszczególnych rejonach województwa małopolskiego. Jest bowiem oczywiste, że kolejny program skierowany na potrzeby rozwoju wsi powinien, jeśli nie usunąć całkowicie, to przynajmniej zmniejszyć istniejące ograniczenia rozwoju, takie jak: ubóstwo występujące na znacznych obszarach województwa, peryferyzacja wielu terenów wiejskich, zmarginalizowany udział dużych grup ludności wiejskiej w tworzeniu dochodu czy malejąca efektywność przestrzeni rolniczej regionu. $\mathrm{W}$ istniejących programach rewitalizacji, przygotowanych przez gminy, wskazuje się przede wszystkim na potrzebę takich działań, które poprawią sytuację ekonomiczną mieszkańców wsi i zwiększą liczbę miejsc pracy, pomogą w zakładaniu podmiotów gospodarczych, poprawią stan infrastruktury drogowej, sanitarnej czy społecznej.

Cel pracy zrealizowano dzięki analizie dokumentów będących podstawą wdrażania programów rewitalizacyjnych. Łączna liczba przeanalizowanych dokumentów wyniosła 122. Dodatkowo przedstawiono zróżnicowanie rozwoju społeczno-gospodarczego gmin wiejskich na podstawie analizy wskaźnikowej oraz identyfikacji typów obszarów wiejskich, mogących być podstawą do zróżnicowania instrumentów w podejściu planistycznym dla przygotowywanych programów rewitalizacji obszarów wiejskich w województwie małopolskim.

\section{Uwarunkowania skuteczności programu}

Jeśli pominąć niezmiernie ważną kwestię dla rewitalizacji obszarów wiejskich, czyli ilość środków finansowych przeznaczonych na realizację założonych zadań, to kolejnym, istotnym celem tego programu pozostaje pozyskanie partnerów wspomagających działania władz. Ta kwestia rozstrzyga się, w pewnym stopniu, już na etapie przygotowywania programów rewitalizacji, kiedy samorząd lokalny konsultuje z mieszkańcami program i zasięga ich opinii na temat zarówno głównych problemów do rozwiązania, jak i miejsc ich szczególnego nasilenia w przestrzeni wsi. W tej sprawie zaobserwować można było dwa sposoby działania władz. Pierwszy z nich to prośba urzędów do mieszkańców jedynie o wypełnienie odpowiedniej ankiety (w gminie Czorsztyn wójt otrzymał tylko jedną ankietę), a drugi, mieszany, to zorganizowanie spotkania z mieszkańcami wsi, by w ten sposób poznać ich opinię (w gminie Łącko w takich spotkaniach wzięło udział 50 osób, a 11 przysłało swoją wypowiedz mailowo). Niezależnie od wyników konsultacji w tych dwóch przykładowych gminach można stwierdzić, że zainteresowanie samych mieszkańców nowym programem pomocowym dla wsi jest prawie wszędzie niewielkie. Brak szerszej reakcji mieszkańców na programy rewitalizacji o tyle dziwi, że jest to przecież 
inicjatywa poprawy ich warunków życia w konkretnym miejscu zamieszkania, w danej części wsi, tam, gdzie mają swoje domy, a nie program dla całej gminy, z którą mogą się w pełni nie utożsamiać. Być może więc władze lokalne powinny do współpracy pozyskać miejscowe instytucje społeczne, takie jak straż pożarna, koła gospodyń czy różne organizacje kulturalne lub wyznaniowe.

Szanse na zrealizowanie wielu zadań rewitalizacyjnych zależą jednak przede wszystkim od tego, w jakim stopniu założenia formalne proponowanych programów uwzględniają charakter regionu i jego specyficzne cechy przyrodnicze, gospodarcze oraz zachowania społeczne i indywidualne mieszkańców. Trzeba przy tym brać pod uwagę duże odrębności przestrzenne w zakresie niemal wszystkich elementów charakteryzujących obszary wiejskie Małopolski. Z analizy dokumentów samorządowych dotyczących omawianego obszaru wynika, że słabo postrzegana jest jego „wiejskość” oraz że istnieją bardzo duże różnice w poziomie urbanizacji i umiastowienia. W liczbie ludności województwa znaczący udział ma aglomeracja krakowska zamieszkana przez blisko milion mieszkańców, co stanowi ok. 30\% ludności województwa. W tym dużym, zurbanizowanym skupieniu mieszka ok. 50\% ludności miejskiej Małopolski, a w samym Krakowie prawie $44 \%$. Wiele powiatów ma bardzo niski odsetek ludności miejskiej i cechuje się brakiem miast o większym potencjale gospodarczym i usługowym. Problem dotyczy w szczególności takich powiatów, jak miechowski, proszowicki, dąbrowski, limanowski, gorlicki czy suski. Tworzą one upośledzone peryferie, których sytuacja wymaga szczególnej uwagi w programach rewitalizacyjnych. Mieszkańcy tych terenów mają utrudniony dostęp do ważnych dzisiaj instytucji konsultingowych, biznesowych czy bankowych, a także związanych z kulturą i oświatą. Obszary wiejskie we wspomnianych częściach Małopolski są też znacznie upośledzone pod względem jakości czynnika ludzkiego - cechują się bowiem niskim udziałem osób lepiej wykształconych i utrzymującym się w wielu gminach regresem demograficznym oraz wzrostem odsetka ludzi starych (do powyżej 20-22\%). Są to czynniki znacznie osłabiające ich rozwój gospodarczy i przedsiębiorczość. Mają one też wpływ na zachowania mieszkańców w takich kwestiach, jak zespołowe formy działania $\mathrm{w}$ rolnictwie, udział w życiu lokalnych społeczności, przyswajanie innowacji czy zdolność do mobilizacji społecznej, niezbędnej dla powstania struktur zbiorowego współdziałania (Hryniewicz, 2000). Tym, jak się wydaje, można w dużym stopniu tłumaczyć wzmiankowany wyżej nikły udział społeczności wielu gmin Małopolski w dyskusji nad założeniami programów rewitalizacji. Innym czynnikiem, który zawsze oddziaływał na warunki rozwoju, jest położenie dużej liczby wsi omawianego regionu na pograniczu polsko-słowackim, cechującym się podobną historią i wspólnotą kulturową. Obecnie istnieje tu bardzo korzystna sytuacja dla podejmowania różnych inicjatyw zespalających to pogranicze w ramach funkcjonującego Euroregionu Tatry.

Cechą szczególną wspomnianej wcześniej wiejskości regionu jest silne przywiązanie ludności zamieszkującej województwo małopolskie do ziemi i jej posiadania, niemające dzisiaj uzasadnienia ekonomicznego, ale głęboko zakorzenione w mentalności mieszkańców i potwierdzające ich wiejską tożsamość. Dlatego udział gospodarstw domowych mających ziemię jest ciągle na większości obszarów wiejskich województwa wysoki i nierzadko dochodzi do 70\%, a w wielu gminach, w pasie ciągnącym się od Jabłonki i Lipnicy Wielkiej, przez Rabkę, Limanową w kierunku Gorlic i Tarnowa, sięga nawet 80\%. Trudno w tych warunkach zmienić w możliwie nieodległej perspektywie rolnictwo regionu, tak w zakresie oczekiwanej poprawy struktury agrarnej, jak i wzrostu produktywności ziemi. 
W podstawowych dokumentach określających gospodarcze aspekty rolnictwa województwa małopolskiego zakłada się, że będzie ono dalej oparte na drobnych i ekstensywnych gospodarstwach oraz tradycyjnych formach gospodarowania (Flaga, Sroka, 2012). Jest to ważne przesłanie dla kształtowania funkcji obszarów wiejskich regionu i przyjętych kierunków ich rewitalizacji, w obrębie których rolnictwo ma wspomagać rolę Małopolski w skali Polski jako osłony ekologicznej kraju (na jego terenie znajdują się źródła wielu rzek karpackich i spore obszary leśne), a także jednego z najważniejszych regionów wypoczynkowych. W tych kwestiach rewitalizacja nie jest podstawowym narzędziem w rozwiązywaniu problemów związanych ze sferą agrarną małopolskiej wsi, niemniej jednak może w sposób znaczący wspierać te segmenty życia społeczno-gospodarczego wsi, które właśnie przez rolnictwo mogą znacznie poprawić poziom dochodów lokalnych społeczności, np. przywracanie na małopolskiej wsi tradycyjnych sposobów gospodarowania w rolnictwie, tradycyjnych produktów żywnościowych i organizowanie lokalnych rynków zbytu (Flaga, Sroka, 2012).

Innym, istotnym jak się wydaje, czynnikiem wspomagającym możliwości zrealizowania wielu zadań rewitalizacyjnych jest wykorzystanie szans, jakie dają wielu gminom różne przedsięwzięcia inwestycyjne czy organizacyjne, prowadzone $\mathrm{z}$ funduszy centralnych lub regionalnych. Chodzi m.in. o to, czy władze lokalne dostrzegają swój rozwój w kontekście wskazanych celów rewitalizacyjnych, takich jak: modernizacja drogi krajowej przebiegającej przez gminę, odwierty wód termalnych (Podhale), oddanie do użytku odcinka autostrady z węzłem drogowym w obrębie rewitalizowanej gminy czy rozbudowa krakowskiej kolei aglomeracyjnej. Studiując opracowanie dotyczące rewitalizacji w podhalańskiej gminie Kościelisko, można zapoznać się z długim fragmentem wyszczególniającym trudne problemy jej mieszkańców związane głównie z regresem sfery turystycznej, który jest w dużym stopniu związany z dostępem komunikacyjnym do tej miejscowości. Pozostał tu, po opuszczeniu przez wojsko, duży kompleks domów wypoczynkowych wraz z otoczeniem, wymagający rewitalizacji. Problem jednak w tym, że zrewitalizowanie tego obiektu zwiększy liczbę miejsc noclegowych, które mogą być słabo wykorzystane, ponieważ znacznie zmalały weekendowe przyjazdy na Podtatrze wskutek dużych trudności komunikacyjnych związanych z przejazdem samochodów na tzw. zakopiance. Do dziś nie wiadomo, w jaki sposób i kiedy poprawi się dostępność komunikacyjna do turystycznych miejscowości Podhala, które jeszcze w latach 90. XX w. były celem cotygodniowych wyjazdów sobotnio-niedzielnych mieszkańców Krakowa.

Istnieje zatem problem powiązania programów rewitalizacyjnych szczebla lokalnego z działaniami w skali regionalnej, obejmującymi duże projekty infrastrukturalne (modernizacja dróg, linii kolejowych, systemów energetycznych), gospodarcze (m.in. pozyskiwanie inwestorów chcących budować tu nowe fabryki, projekty ożywienia rolnictwa na terenach, gdzie ta działalność nadal zanika, inwestycje w usługi rekreacyjne), czy społeczne, służące lepszej możliwości zdobywania wiedzy przez młodzież, m.in. przez budowę szerokopasmowego Internetu, wprowadzanie programów przeciwdziałających wykluczeniu społecznemu ludności czy programów organizowania na wsi domów kultury, filii bibliotek itp. Jednak rzadko w programach gminnych rewitalizacji spotkać można takie podejście, w którym wiąże się zadania lokalne z działaniami regionalnymi. Pozytywnym tego przykładem jest inicjatywa kilku gmin z doliny Raby - Rabki, Raby Wyżnej i Spytkowic oraz dwóch gmin orawskich - Jabłonki i Lipnicy Wielkiej, które wykorzystując sytuację spodziewaną po zmodernizowaniu kolejnego odcinka zakopianki pomiędzy 
Lubniem a Chabówką, chcą zorganizować na swoim terenie miejsca sprzyjające wypoczynkowi i rekreacji. Liczą bowiem na to, że już w roku 2020 będzie można dojechać tu z Krakowa i jego okolicy w niespełna godzinę. Spodziewają się też szybszego powiązania kolejowego w związku z zapowiadaną modernizacją linii Kraków-Zakopane i Sucha Beskidzka-Chabówka. Działając z tą myślą, ubiegają się o środki unijne, z przeznaczeniem na rewitalizację centrów wsi, rozwój gospodarstw agroturystycznych, modernizację szlaków turystycznych i ścieżek rowerowych, renowację obiektów kulturowych, a także na promocję lokalnej turystyki. Chcą też przygotować atrakcyjne tereny, położone przy drodze E7, pod nowe inwestycje produkcyjne i usługowe.

Tworzone od początku lub aktualizowane gminne programy rewitalizacji wsi nie są zupełnie nową projekcją rozwoju obszarów wiejskich, ale jednym z kolejnych etapów rozwiązywania kluczowych problemów społeczno-gospodarczych, występujących w regionie małopolskim. Powinny mieć zatem swoje umocowanie w już istniejących lub powstających obecnie działaniach związanych z funduszami Rozwoju Obszarów Wiejskich, przeznaczonymi dla województwa. Trzeba w związku z tym przypomnieć, że władze regionalne przygotowały i wdrażają wiele programów, których cele są zbieżne z postulowanymi zadaniami rewitalizacji wsi (por. Flaga, Sroka, 2012). Jednym z nich jest program ożywienia pasterstwa na obszarach górskich województwa małopolskiego, przyjęty jeszcze w 2005 r., którego częścią jest nagłośniony ostatnio w mediach projekt Urzędu Marszałkowskiego Województwa Małopolskiego dotyczący kształcenia baców i juhasów. Projekty te mają z jednej strony poprawić wykorzystanie lokalnej bazy paszowej na terenie Podhala przez powrót do dawnej, znacznie większej niż obecnie, skali chowu owiec i bydła, a z drugiej przywrócić tradycje pasterskie w wymiarze kulturowym, postrzegane jako istotny element atrakcyjności turystycznej wsi. Jak jednak pokazują statystyki, te programy nie przynoszą spodziewanych rezultatów, ponieważ w przypadku hodowli bydła notuje się dalsze spadki jego pogłowia (np. pomiędzy 2013 a 2014 r. ogólne pogłowie bydła zmniejszyło się o $0,7 \%$, w tym sztuk mlecznych aż o 5,6\%, a pogłowie owiec było nadal niewielkie i w podanym okresie wzrosło tylko o niecały 1 punkt procentowy). Inne projekty urzędu to budowa i modernizacja dróg w gminach położonych blisko węzłów autostradowych, a także porządkowanie przestrzeni wsi, w tym dotyczące głównie likwidacji powszechnej w województwie małopolskim szachownicy gruntów rolniczych. Przygotowywane w tej ostatniej sprawie projekty obejmą w pierwszej kolejności gminy położone na wschód i zachód od Krakowa oraz na północy regionu, w gminach z dobrymi glebami.

W wytycznych dotyczących programów rewitalizacji znalazł się obligatoryjny nakaz, by teren rewitalizowany obejmował nie więcej niż 20\% powierzchni gminy i był zamieszkany przez nie więcej niż 30\% jej ludności. Podmiotem działań tego projektu jest wieś, w której największą część przestrzeni zajmują użytki rolne lub leśne, a znikomy procent - zabudowa i infrastruktura nawierzchniowa. Wiele problemów, które w programach rewitalizacji są w województwie małopolskim wskazywane jako najpilniejsze do rozwiązania, nie ma charakteru przestrzennego, ale dotyczy istotnych ograniczeń gospodarczych czy społecznych (nierentowne rolnictwo, ubóstwo mieszkańców wynikające z niskich dochodów z rolnictwa, bezrobocie, wykluczenie, starość, brak dostępu do kultury). Tych problemów nie rozwiąże się przez wskazanie miejsca we wsi, w którym znajduje się obiekt lub trudny do rozwiązania przez rewitalizację problem (np. bieda czy duża skala przestępczości). W programie gminy Spytkowice, która składa się tylko z jednej, ale bardzo dużej 
wsi, liczącej ponad 5 tys. mieszkańców, wydzielono obszary do rewitalizacji, które miały odpowiadać wymogom założonym w programie. Wieś ma charakter łańcuchówki, którą trzeba było podzielić w taki sposób, by wyróżnione części spełniały przede wszystkim kryteria przestrzenno-ludnościowe. Jak się jednak wydaje, pozostałe jej obszary również mają problemy z bezrobociem, starością czy wykluczeniem społecznym, a więc z tymi ograniczeniami życia, które zidentyfikowano do rewitalizacji tylko w kilku miejscach Spytkowic. W tym kontekście można stwierdzić, że dla podejmowanych programów rewitalizacyjnych podstawową kwestią nie jest wskazanie w przestrzeni wsi problemów do rozwiązania, lecz określenie ich istotności dla całego zbioru mieszkańców oraz ukazanie sposobu rozwiązania.

\section{Główne cele rewitalizacji wsi w województwie małopolskim}

Cele te są zróżnicowane, ponieważ współczesna przestrzeń wiejska regionu nie jest jednorodna, zarówno w wymiarze ekonomicznym, jak i społecznym czy kulturowym. Niemniej jednak na przeważającym obszarze głównym problemem pozostają kwestie wynikające z niskich dochodów ludności, których pochodną jest ubóstwo, wykluczenie społeczne i marginalizacja dużych nieraz grup ludności. Nieprzypadkowo więc w materiałach Urzędu Marszałkowskiego wskazano obszary strategicznej interwencji, zajmujące priorytetowe miejsce w programach rewitalizacji jako tereny dużego ubóstwa. Najwięcej gmin zdiagnozowanych $\mathrm{w}$ tych materiałach jako najbiedniejsze w Małopolsce znajduje się w powiatach: gorlickim, nowosądeckim, limanowskim i myślenickim. Dużo jest ich także w północno-wschodniej części regionu, w powiatach dąbrowskim i tarnowskim oraz na południu, w powiecie suskim.

Najważniejsze dla określenia działań mogących zlikwidować lub ograniczyć biedę na tych terenach jest wskazanie jej przyczyn. Można je wiązać z niską efektywnością ekonomiczną przestrzeni wiejskiej i brakiem silnych ośrodków gospodarczych skupionych $\mathrm{w}$ miastach. Tereny najbiedniejsze to $\mathrm{w}$ większości obszary $\mathrm{z}$ dominującą funkcją rolniczą i dosyć wolno rozwijającą się turystyką, położone w strefach słabo zurbanizowanych. Można w tym miejscu postawić pytanie: W jakim stopniu samo rolnictwo generuje w Małopolsce biedę i czy jest ono rzeczywiście istotną przyczyną wskazanego w materiałach Urzędu Marszałkowskiego ubóstwa na terenie wymienionych wcześniej powiatów? Produktywność małopolskiego rolnictwa jest niska i z każdym rokiem spada. Kurczą się powierzchnie upraw głównych roślin, zmniejsza się też pogłowie hodowanych zwierząt. Gospodarowanie na małych powierzchniach, które posiadają tutejsi rolnicy, jest ekonomicznie nieopłacalne, szczególnie na słabszych glebach, dominujących w gminach górskich i pogórskich. Jednak w dyskusjach o przyszłości polskich wsi zwraca się uwagę (Zegar, 2012) na ważne, pozaprodukcyjne ich funkcje, bardzo istotne dla zachowania żywotności obszarów wiejskich i urzeczywistnienia idei zrównoważonego rozwoju. W tym zakresie, jak pisze Zegar (2012), gospodarstwa małe odgrywają znacznie większą rolę aniżeli w sferze produkcji rolnej. W podejściu do obszarów z drobnymi gospodarstwami, które dominują w województwie małopolskim, trzeba kierować się innymi kryteriami dotyczącymi ich trwania niż na terenach z dużymi jednostkami. Jeśli bowiem założymy potrzebę zachowania na Małopolskiej wsi dawnych zwyczajów, dziedzictwa kulturowego i tradycji, a także ochronę tutejszej przyrody, to największe możliwości takich działań dają małe gospodarstwa rodzinne (Zegar, 2012). W chwili obecnej problemem pozostaje ich trudna 
sytuacja ekonomiczna, ponieważ dochody uzyskiwane z prowadzenia gospodarstw w województwie małopolskim spadają i nie da się tego ubytku łatwo zrekompensować przychodami uzyskiwanymi przez właścicieli małych gospodarstw z pracy pozarolniczej, której zwykle w regionach rolniczych nie ma. Spadające przychody z rolnictwa wiążą się tutaj przede wszystkim z rezygnacją części gospodarstw z prowadzenia produkcji roślinnej i zwierzęcej. Badania pokazują, że roczne ubytki w powierzchni użytków rolnych wynoszą w województwie ok. 12 tys. ha. Szybko zmniejsza się obszar przeznaczany corocznie pod uprawy zbóż i roślin okopowych (Głębocki, 2014). Procesy te mają różną skalę w poszczególnych częściach województwa. Szczególnie duże zmiany w użytkowaniu gruntów widać na terenach o trudnych warunkach glebowo-klimatycznych. W dużej gminie orawskiej, Jabłonce, jeszcze niedawno pod zasiewy przeznaczano ponad 8 tys. ha, a obecnie jest to tylko ok. 600 ha. Wypadająca spod upraw ziemia powiększa powierzchnię użytków zielonych, na których jednak teraz wypasa się znacznie mniej bydła i owiec niż w przeszłości. W innych obszarach regionu procesy te zachodzą wolniej, ale prawie wszędzie spada intensywność rolnictwa i nie poprawia się jego kosztochłonność. Z analizy poziomu intensywności rolnictwa województwa małopolskiego przeprowadzonej metodą B. Kopcia (1964) wynika, że w przypadku produkcji roślinnej intensywność rolnictwa spadła do bardzo niskiego poziomu na wspomnianych obszarach Karpat i Pogórza - jest ona tam ponad trzy-, a nawet czterokrotnie niższa niż na obszarach Wyżyny Miechowskiej o dobrych glebach czy też w strefie podkrakowskiej skupiającej dużą produkcję warzyw. Poziom intensywności produkcji w okresie między spisami rolnymi zmniejszył się o ponad 10 pkt z 120,95 pkt w 2002 do 110,7 pkt w 2010 r. Silne trendy spadkowe widoczne są również w produkcji zwierzęcej, bowiem w większości gmin Małopolski (w 127, tj. 69,8\% ogółu) odnotowano w latach 2002-2010 wyraźne obniżenie intensywności tej gałęzi rolnictwa, przy czym aż w 72 gminach było ono duże i bardzo duże (średnio w tych gminach intensywność spadła o $50 \mathrm{pp}$ ).

Niekorzystne tendencje zachodzące w rolnictwie związane są z jego cechami strukturalnymi, a więc z jego rozdrobnieniem, obciążeniem gospodarstw dużą liczbą pracujących na roli, a przede wszystkim - z brakiem odpowiedniej polityki w stosunku do małych gospodarstw i obszarów, na których są one dominującym elementem rolniczych systemów gospodarczych. Brak takiej polityki powoduje, że nie udaje się tutaj tworzyć zespołowych form gospodarowania, modernizować małych gospodarstw rolnych ani też uzyskiwać odpowiednich dopłat przewidzianych w unijnych systemach wspierania rolnictwa. W 2014 r. tylko 75\% gruntów rolnych Małopolski objętych zostało dopłatami rolniczymi, gdy w kraju było to $90 \%$.

Jednak od pokoleń trudnym problemem związanym z rolnictwem Małopolski i z tutejszymi gospodarstwami jest bardzo duża liczba zatrudnionych osób. Według szacunków w roku 2013 mogła ona wynosić 272 tys. (jest to 27,2\% ogółu pracujących w regionie). Ta liczba znacznie przekracza potrzeby tutejszych gospodarstw, dlatego istniejące nadwyżki siły roboczej tworzą tzw. „bezrobocie utajone”, ale problemu jego istnienia nie da się łatwo rozwiązać bez zmian strukturalnych w rolnictwie i wielu innych działań związanych z pozarolniczą sferą gospodarki wiejskiej.

W części powiatów udział osób związanych z rolnictwem w ogólnej liczbie pracujących wynosi nawet 60-70\%, a jedynie w części zachodniej regionu jest niski i kształtuje się poniżej $20 \%$. Są dwa obszary o wysokim zatrudnieniu w rolnictwie - jeden tworzą powiaty rolnicze (miechowski, proszowicki, tarnowski), a drugi - biedne powiaty pogórskie 
Ryc. 1. Intensywność produkcji roślinnej w 2010 r. i dynamika zmian w latach 2002-2010

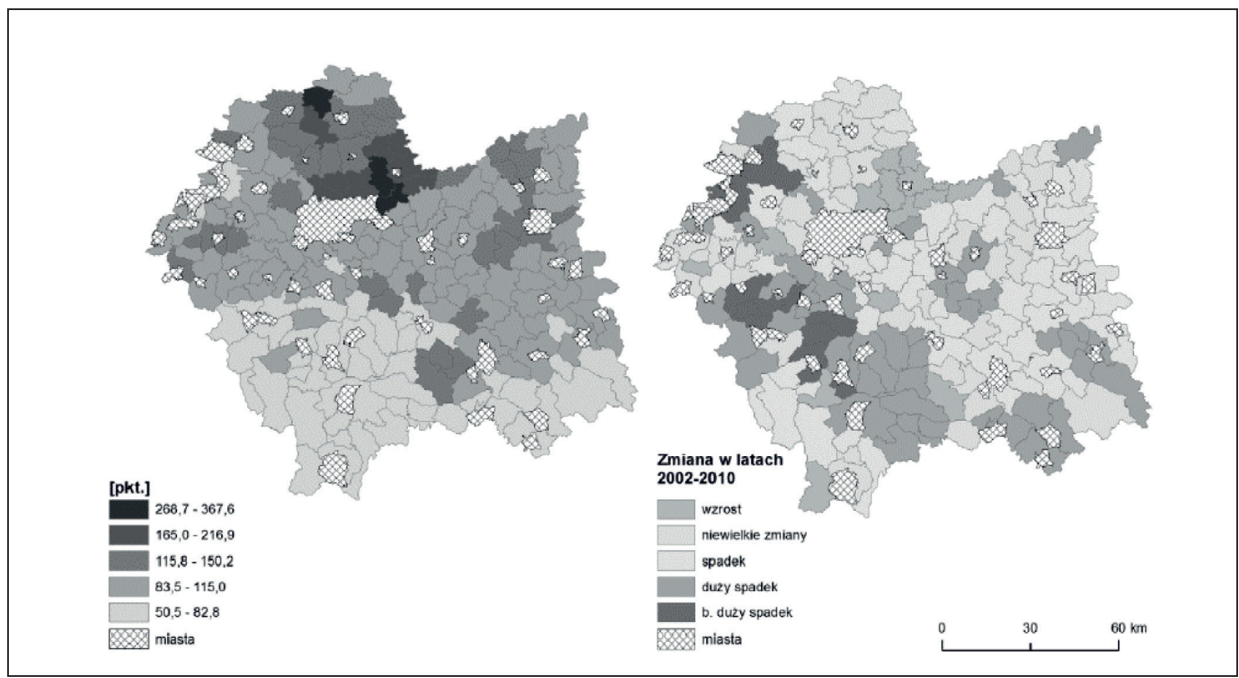

Źródło: opracowanie własne na podstawie: Główny Urząd Statystyczny (2010)

Ryc. 2. Intensywność produkcji zwierzęcej w 2010 r. i dynamika zmian w latach 2002-2010

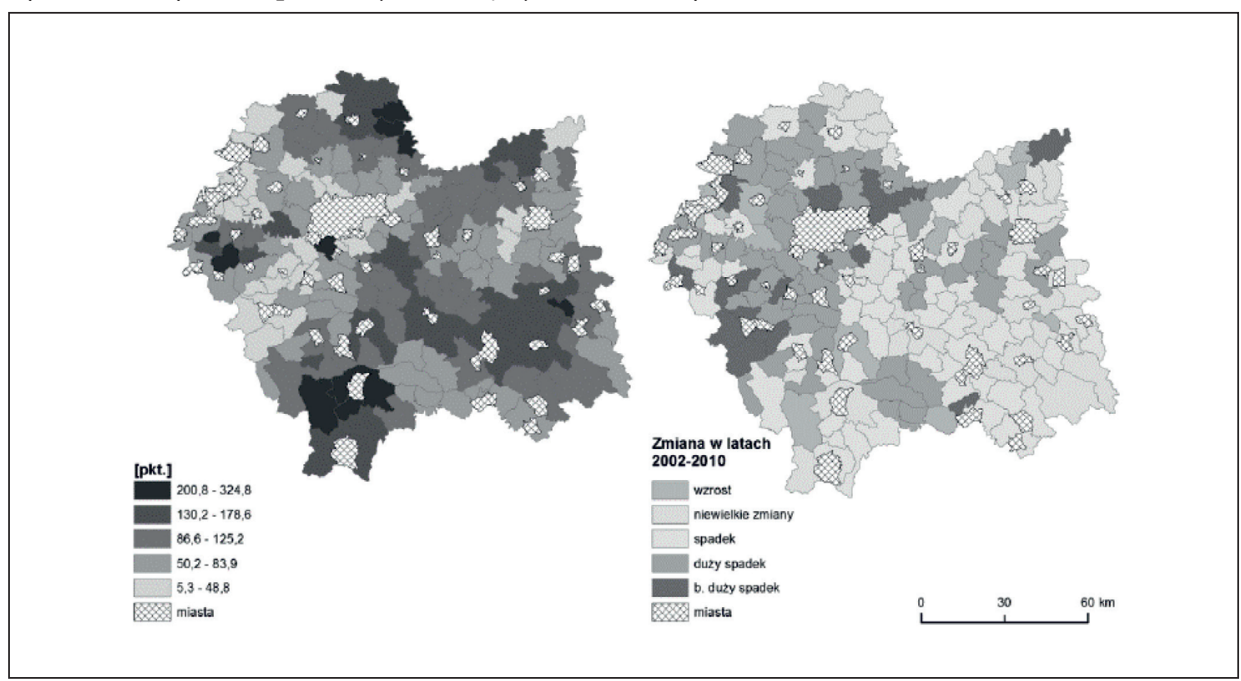

Źródło: opracowanie własne na podstawie: Główny Urząd Statystyczny (2010)

i górskie, gdzie występuje duże rozdrobnienie gospodarstw i brak lokalnych ośrodków zatrudnienia pozarolniczego (ryc. 3). Słabo rozpoznany jest status zawodowy tych osób, bowiem duża ich część formalnie pozostaje w gospodarstwie i korzysta z przywilejów KRUS, ale faktycznie pracuje poza rolnictwem. Znane są różne formy tego zatrudnienia nie odnotowane w oficjalnych statystykach, takie jak praca w nieformalnych grupach budowlanych prowadzących budowy domów w różnych miastach Polski (Górz, 2003) czy też emigracja zarobkowa do Niemiec, Austrii, Włoch, Wielkiej Brytanii oraz krajów skandynawskich. Zwłaszcza ta ostatnia forma zatrudnienia ludności z gospodarstw rolnych odbywa 
Ryc. 3. Pracujący w rolnictwie w ogólnej liczbie pracujących w roku 2013 (w procentach)

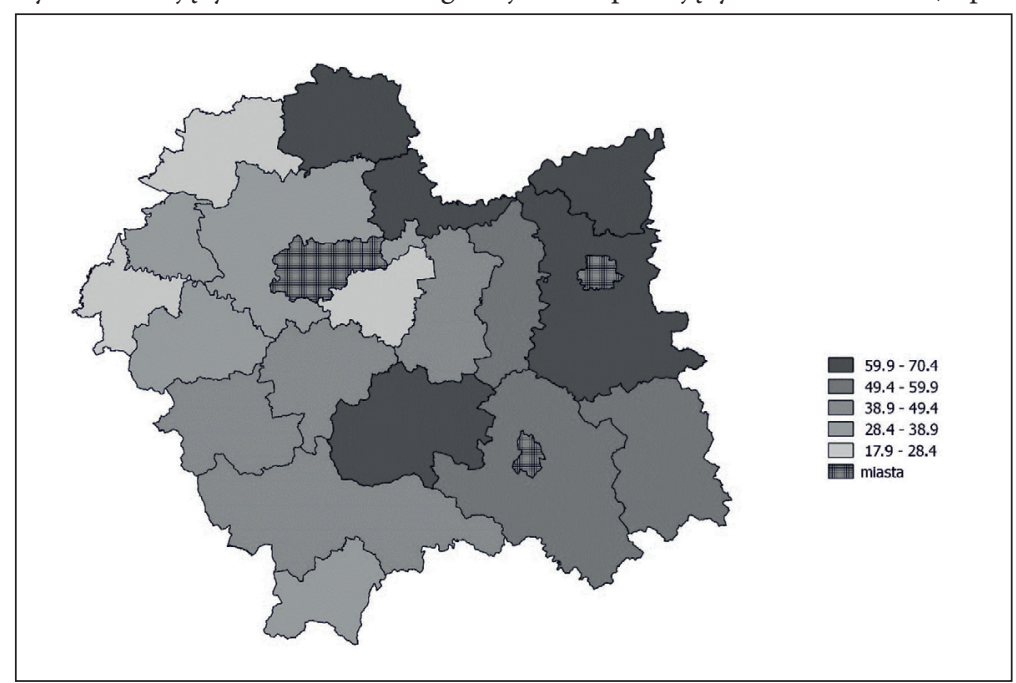

Źródło: opracowanie własne na podstawiepodstawie: Główny Urząd Statystyczny (2010)

się obecnie na dużą skalę. Zagadnienie to dla Podhala badał Edward Siarka, który stwierdził, że w 2008 r. z powiatu nowotarskiego mogło za granicą pracować 25\% ogółu osób w wieku produkcyjnym (Leśniak, 2009). Wyjazdy do pracy za granicę są w Małopolsce powszechne, bo jest to wysoce konkurencyjny sposób pozyskiwania dochodów, szczególnie w stosunku do rolnictwa. Mają one obecnie duży wpływ na kształtowanie ekonomii obszarów wiejskich regionu. Ale te wyjazdy zarobkowe są też poważnym ograniczeniem dla lokalnej gospodarki, bo uczestniczą w nich osoby przedsiębiorcze, posiadające na ogół określone przygotowanie zawodowe, których w kraju będzie coraz bardziej brakować

Problemy rolnictwa są często podnoszone w programach rewitalizacyjnych władz samorządowych w kontekście zakładanych modeli rozwojowych gmin. W regionach górskich i pogórskich (głównie w regionie Podhala i Beskidu Sądeckiego) kierunkiem docelowym tego rozwoju ma być ekoturystyka oparta na gospodarstwach agroturystycznych i ekologicznym rolnictwie (Gil, 2014). Ma ona także korzystać z lokalnych tradycji kulinarnych i wytwarzanych w gospodarstwach produktach. Tym oczekiwaniom wychodzi naprzeciw Program rozwoju tradycyjnego rolnictwa, w tym głównie sadownictwa, pszczelarstwa, owoców miękkich, a także winiarstwa oraz rybactwa, realizowany w województwie od końca 2010 r. Zakłada on wspieranie chowu tradycyjnych gatunków bydła i owiec, dostosowanego do warunków lokalnych, upowszechnianie dawnych odmian roślin, które mają być uprawiane metodami ekologicznymi. W ten sposób ma się tutaj uzyskiwać produkty wysokiej jakości, które będą sprzedawane w miejscowych sklepach oraz na bazarach. Te ostatnie mają być bardziej niż teraz obecne, szczególnie w miejscowościach turystycznych, gdzie przyjezdni mogą się zaopatrywać w lokalne produkty żywnościowe. Priorytetem mają być produkty regionalne. Dotychczas w regionie zarejestrowano ich prawie 150, co stanowi 10\% ich krajowej liczby (m.in. oscypek, śliwowica łącka, charsznicka kapusta kwaszona). Ze wzmacnianiem funkcji turystycznych rolnictwa wiążą się nowe szlaki turystyczne, takie jak Małopolska Miodowa Kraina czy Małopolska Wieś Pachnąca Ziołami (Jakóbik, 2015). Na potrzeby realizacji tych projektów samorządy chcą 
skorzystać z funduszy rewitalizacyjnych oraz innych, przeznaczonych dla gmin w kolejnych programach operacyjnych. Jest to bardzo ważny kierunek działań lokalnych mający wymiar nie tylko ekonomiczny, ale także społeczno-kulturowy.

Główne typy przestrzeni wiejskiej województwa małopolskiego i ich potrzeby rewitalizacyjne

W przedstawionych dotąd materiałach zwracano uwagę na duże zróżnicowanie obszarów wiejskich województwa małopolskiego pod względem głównych potrzeb rewitalizacyjnych i możliwości ich realizacji w ramach kolejnej perspektywy finansowej. W tym kontekście starano się poniżej wyróżnić określone grupy gmin, cechujących się podobieństwem cech w zakresie ukształtowanej struktury społeczno-gospodarczej oraz potrzeb rozwojowych optymalizujących te struktury, których efektem powinna być poprawa warunków życia w wymiarze ekonomicznym, kulturowym i cywilizacyjnym oraz szeroko rozumiany awans społeczny. Podstawą grupowania gmin były dane udostępniane przez GUS, charakteryzujące ich stan społeczny oraz lokalną gospodarkę. Przyjęto w sumie $10 \mathrm{cech}$ :

- saldo migracji (średnia 2012-2014),

- gęstość zaludnienia (2014),

- intensywność produkcji zwierzęcej (2010),

- intensywność produkcji roślinnej (2010),

- średnia powierzchnia gospodarstw powyżej 1 ha (2010),

- wskaźnik atrakcyjności turystycznej Warszyńskiej,

- liczba udzielonych noclegów/1000 mieszkańców (2014),

- liczba zarejestrowanych podmiotów gospodarczych w systemie REGON na 1000 mieszkańców (2014),

- dochody budżetowe gmin na 1 mieszkańca (2014),

- \% dochodów własnych gmin w ich ogólnych dochodach budżetowych (2014).

Cechy te poddano standaryzacji przy pomocy metody unitaryzacji zerowanej (MUZ) wg wzoru:

$$
z_{i j}=\frac{x_{i j}-\min _{i} x_{i j}}{\max _{i} x_{i j}-\min _{i} x_{i j}}
$$

Po otrzymaniu wyników zestawiono wszystkie gminy w 5 grupach nazwanych typami przestrzeni wiejskiej (typ rolniczy, turystyczny - w tym podtyp o dużym potencjale rozwoju - podmiejski, wielofunkcyjny obszar przejściowy oraz mieszany). Wyróżnione typy pozwoliły utworzyć 5 obszarów z gminami cechującymi się dominacją lub przewagą poziomu badanych cech społeczno-gospodarczych.

Trzy spośród pięciu wyróżnionych typów obszarów, mianowicie obszar rolniczy, turystyczny i podmiejski, mają już wyraźnie wykształcony kierunek rozwoju, odpowiadający posiadanym zasobom przyrodniczym lub funkcji wynikającej z położenia w przestrzeni regionu. Natomiast dwa pozostałe będą podlegać dalszym zmianom, przy czym położony w zachodniej części regionu wielofunkcyjny obszar przejściowy przez rewitalizację może powrócić do dawnej funkcji przemysłowej. 
Ryc. 4. Typy przestrzeni wiejskiej województwa małopolskiego wg cech ukształtowanej struktury społeczno-gospodarczej

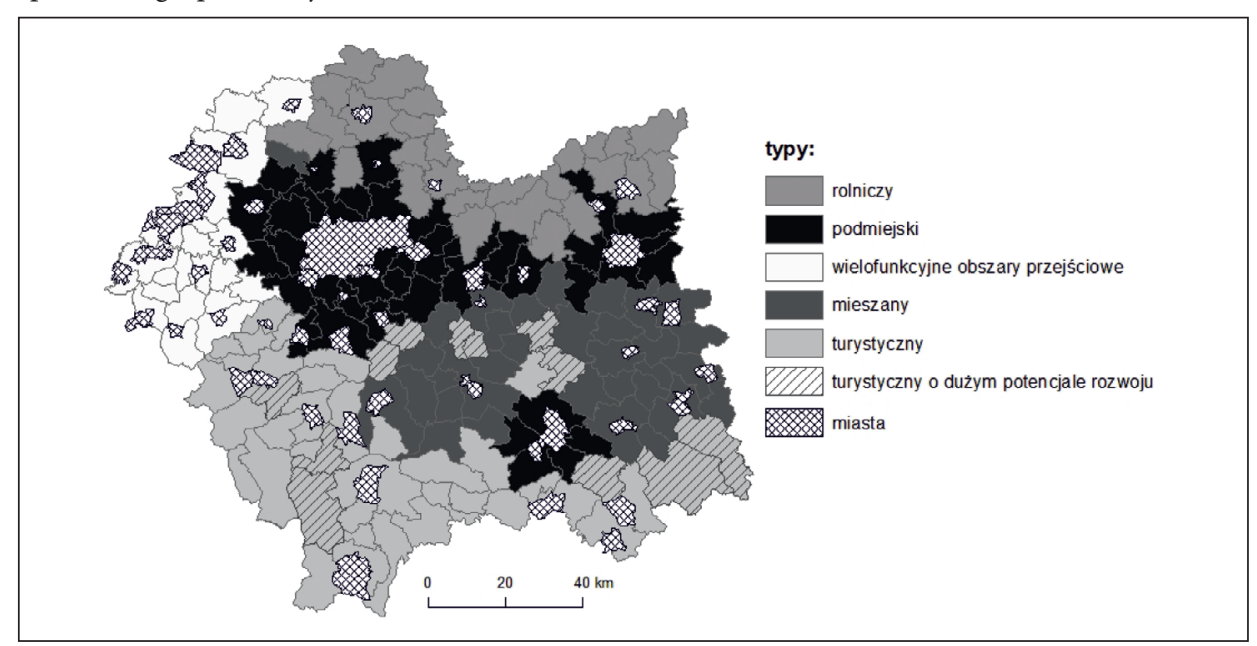

Źródło: opracowanie własne

Największy powierzchniowo jest w województwie małopolskim typ turystyczny, który obejmuje łącznie 51 gmin. W jego obrębie można wyróżnić dwie grupy gmin - z silnie rozwiniętą turystyką (39), która jest tu głównym zajęciem ludności (cały powiat tatrzański, większość terenów powiatu nowotarskiego, duże części powiatu nowosądeckiego i gorlickiego) i drugą z gminami Pogórza Karpackiego, o dobrych warunkach dla turystyki wypoczynkowej i rekreacyjnej, mogących stanowić tereny wyjazdów weekendowych i wakacyjnych dla mieszkańców aglomeracji krakowskiej (12 gmin). W pierwszym z tych obszarów turystycznych kluczowe problemy ich bieżącego i perspektywicznego rozwoju dotyczą poprawy dostępności komunikacyjnej, przywracania i wzmacniania tradycji kulturowych, poprawy estetyki wsi oraz rozbudowy szeroko rozumianej bazy turystycznej. Ważnym segmentem ich rozwoju jest też zagospodarowanie gruntów ugorujących, wcześniej użytkowanych rolniczo, na których można prowadzić wypas owiec i bydła. Natomiast we wsiach Pogórza Karpackiego, zależnie od warunków lokalnych (zróżnicowania rzeźby, obecności wód powierzchniowych nadających się do kąpieli, dostępnych komunikacyjnie), problemem jest słaba baza rekreacyjno-wypoczynkowa i sportowa, brak noclegów i dobrej gastronomii. Na Pogórzu istnieje w dalszym ciągu rolnictwo, a w części wsi także sadownictwo i uprawa owoców miękkich. Tutaj samorządy powinny zadbać o gospodarstwa agroturystyczne z tradycyjną kuchnią i zdrową żywnością. Planowane jest w tym zakresie wsparcie $\mathrm{z}$ funduszy europejskich, którego część będzie przeznaczona na budowę targowisk i bazarów, gdzie rolnicy mogliby sprzedawać własne wyroby z gospodarstw ekologicznych. Turystyka w opisywanym obszarze Małopolski powinna uzyskać silne wsparcie w lokalnych programach rewitalizacyjnych w zakresie modernizacji centrów wsi, odnowy zabytków czy wspierania tradycji rolniczych i kulturowych. W tym procesie dobre perspektywy mają lokalne grupy działania, łączące wysiłek nad wypromowaniem określonych produktów turystycznych.

Zdefiniowaną perspektywę rozwoju ma też rolniczy typ obszaru obejmujący północne części województwa małopolskiego w granicach powiatu miechowskiego, 
proszowickiego, dąbrowsko-tarnowskiego i tarnowskiego. Tutaj programy rewitalizacyjne powinny wspomagać mieszkańców w poprawie ich warunków życia w zakresie dostępu do informacji, szeroko rozumianej kultury oraz usług handlowych, zdrowotnych i oświatowych. Z powodu postępującej depresji demograficznej kurczy się w wielu gminach baza kształcenia dzieci i młodzieży (Gil, Semczuk, 2015) i pogarszają możliwości awansu cywilizacyjnego. Miejscowe samorządy dysponują niewielkimi budżetami, by mogły, bez pomocy zewnętrznej, poprawić sytuację samego rolnictwa, wymagającego reformy agrarnej (głównie likwidacji szachownicy gruntów) i zbudowania odpowiedniego otoczenia ekonomicznego dla tutejszych gospodarstw. W przygotowywanych programach rewitalizacyjnych podkreśla się jako potrzeby kluczowe - złagodzenie ubóstwa, poprawę komunikacji, zwiększenie liczby miejsc pracy, a także starania o bazę dla rekreacji i wypoczynku, w tym szczególnie dla osób starszych, których liczba stale rośnie (zobacz np. „Program rewitalizacji dla miasta i gminy Miechów”). W dużej części obszarów rolniczych przeważa rozdrobniona sieć osadnicza z niewielką liczbą ludności dotkniętej tymi samymi problemami ekonomicznymi i społeczno-cywilizacyjnymi. Trudno w tej sytuacji wskazać te ich części, które będą objęte programami rewitalizacyjnymi, z pominięciem pozostałych.

Trzeci spośród wyróżnionych typów - typ podmiejski - tworzy pierścień gmin przyległych do Krakowa i dwóch innych miast regionu (Tarnowa i Nowego Sącza). Cechują się one silnie przekształconymi strukturami gospodarczymi, ludnościowymi i odmiennymi wzorcami zachowań kulturowych. Gminy te są od dawna powiązane z miastami i pełnią nie tylko funkcje sypialne, ale także ekonomiczne i rekreacyjno-wypoczynkowe. Kluczowym problemem obszarów podmiejskich jest poprawa komunikacji i dostępu mieszkańców do miast, gdzie nie tylko pracują, ale także kształcą się i korzystają z różnych usług. Strefy podmiejskie zagęszczają się szybko w procesie tzw. dekoncentracji osadniczej, prowadzącej także do odmłodzenia struktury wieku ludności. W programach rewitalizacyjnych podkreśla się potrzebę integracji mieszkańców w obrębie wsi i ich uspołecznienia, dlatego częste są postulaty odnowy istniejących obiektów, takich jak świetlice, domy kultury, biblioteki, w których można organizować spotkania i dyskusje. Problemem gmin podmiejskich jest także ich słaba spójność wewnętrzna, bowiem z tytułu renty położenia bardzo szybko rozwijają się wsie dobrze skomunikowane z miastami, co można w szczególności zaobserwować np. w gminie Zielonki, Michałowice czy Zabierzów, a znacznie wolniej - położone na peryferiach gmin.

Znaczną powierzchnię zajmuje w regionie małopolskim mieszany typ obszarów wiejskich. Należące do niego gminy znajdują się prawie w całości na Pogórzu Karpackim, w pasie ciągnącym się od Mszany Dolnej aż do granicy z województwem podkarpackim. Głównym problemem tego obszaru jest ubóstwo, a źródłem biedy jest peryferyjność położenia, rozdrobnione rolnictwo, duża liczba zbędnych osób związanych z rolnictwem, a także brak postępu w rozwoju wielofunkcyjnej gospodarki wiejskiej. Z rewitalizacją tej części Małopolski wiązać można przede wszystkim lokalne przetwórstwo produktów rolnych, oparte na tradycyjnych i nowych recepturach, którego przykładem może być łącka śliwowica czy tłoczenie soków jabłkowych, malinowych, a także wiele innych przetworów, dostępnych już teraz na targowiskach i wiejskich bazarach. Innym kierunkiem działalności gospodarczej jest organizowanie grup producenckich wspieranych przez kapitał zewnętrzny i tworzenie większych zakładów przetwórstwa rolno-spożywczego, takich jakie działały w czasach PRL-u w Nowym Sączu, a obecnie w miejscowości Olszana w powiecie 
nowosądeckim. Analizowany typ obszaru jest wewnętrznie zróżnicowany, co wiąże się głównie z warunkami środowiskowymi i dostępnością komunikacyjną. Niemniej jednak w większości gmin można znacznie zintensyfikować uprawy roślin pracochłonnych i zorganizować wspomniane przetwórstwo rolno-spożywcze. W kilkunastu gminach położonych w Beskidzie Wyspowym istnieją już od dawna intensywne sadownictwo oraz uprawy szklarniowe zajmujące znaczne powierzchnie. Ten sektor drobnego rolnictwa ma tu dobre perspektywy, ale musi być wspomagany funduszami zewnętrznymi i działaniami organizacyjnymi dostosowanymi do lokalnych warunków. Duże nadzieje dla rozwoju omawianej grupy gmin wiejskich wiążą mieszkańcy z zapowiadaną budową drogi ekspresowej wiodącej od węzła autostradowego w Brzesku do Nowego Sącza.

Ostatni typ obszarów wiejskich, nazwany wielofunkcyjnym obszarem przejściowym, obejmuje 25 gmin i obok wspomnianych wcześniej obszarów podmiejskich, ma silnie zmienioną strukturę gospodarczą i społeczną (ryc. 4), ukształtowaną głównie przez istniejący tu przemysł oraz dojazdy do pracy mieszkańców na Górny Śląsk. Najważniejszym zasobem tej części regionu Małopolski jest dobra jakość kapitału ludzkiego, tradycje przemysłowe, korzystne położenie i dobra dostępność komunikacyjna. Natomiast współczesne ograniczenia rozwojowe wiążą się w znacznym stopniu z upadkiem działających tutaj od dawna zakładów przemysłowych (m.in. Zakłady Obuwnicze w Chełmku, Fabryka Naczyń Emaliowanych w Olkuszu) i bardzo powolną ich rewitalizacją. Rezultatem upadłości jest bezrobocie, spadek dochodów ludności i relatywne pogorszenie sytuacji materialnej. Jakkolwiek w przygotowywanych przez tutejsze samorządy programach rewitalizacji zwraca się uwagę na potrzebę rozwoju infrastruktury służącej wypoczynkowi, rekreacji czy integrowaniu społeczeństwa (ścieżki rowerowe, siłownie, pływalnie, kluby, świetlice, kawiarnie), to za najważniejsze sprawy do rozwiązania uznają mieszkańcy biedę, bezrobocie i brak perspektyw dla młodego pokolenia. Zatem, jeśli rewitalizacja ma tutaj spełnić oczekiwania społeczne, powinna głównie koncentrować się na zwiększeniu liczby miejsc pracy i aktywizacji działań ekonomicznych ludności. Szczególnie ważne wydaje się tutaj wykorzystanie endogenicznych czynników rozwoju związanych z rewitalizacją przemysłu.

\section{Zakończenie}

Obecna perspektywa finansowa dla polskich wsi, związana także z wdrażanym programem rewitalizacji obszarów wiejskich, poszerza znacznie możliwości ich rozwoju nie tylko w sferze ekonomicznej, ale też w sferach kulturowej, społecznej i cywilizacyjnej. Jednak najważniejsze do rozwiązania problemy Małopolski dotyczą biedy, bezrobocia i lepszej przyszłości, bo te elementy życia mieszkańców mają kluczowe znaczenie dla budowania lokalnej tożsamości i wiązania ludności wiejskiej z miejscem zamieszkania. Jak się wydaje, bardzo ważnym podejściem w programach rewitalizacyjnych dotyczącym ich skuteczności jest dążenie do budowania szerokiej bazy interesariuszy i wsparcia społecznego, a także akcentowanie takich działań, które tworzą materialne warunki integracji mieszkańców wokół spraw najtrudniejszych, występujących w miejscu ich zamieszkania. Trudno jednak oczekiwać, że podejmowane w ramach rewitalizacji działania rozwiążą istniejące w regionie sprawy ze wszystkich sfer życia mieszkańców wsi, ponieważ np. kwestia ubóstwa ma w wielu gminach tak dużą skalę i utrwalony charakter, że wymaga dużego wsparcia zewnętrznego. 
Literatura

References

Flaga, S., Sroka W. (2012). Gospodarcze aspekty rolnictwa. Kraków: Urząd Marszałkowski Województwa Małopolskiego.

Gil, A., (2014). Współczesne funkcje rolnictwa Małopolski. W: R. Rudnicki, M. Kluba (red.), Zintegrowany rozwój obszarów wiejskich w świetle polityki Unii Europejskiej. Tom 1: Rolnictwo i Wspólna Polityka Rolna. Toruń: Wydawnictwo Naukowe Uniwersytetu Mikołaja Kopernika, 49-170.

Gil, A., Semczuk, M. (2015). Dostępność edukacji podstawowej na obszarach wiejskich województwa małopolskiego - studium przypadku powiatu miechowskiego. Studia Obszarów Wiejskich, 40, 65-80.

Głębocki, B. (2014). Zmiany w strukturze agrarnej polskiego rolnictwa w latach 2002-2012. W: B. Głębocki (red.), Zróżnicowanie przestrzenne rolnictwa. Warszawa: GUS, 14-71.

Główny Urząd Statystyczny (2010), Powszechny Spis Rolny 2010 - Użytkowanie gruntów. Pozyskano z: http:// stat.gov.pl/obszary-tematyczne/rolnictwo-lesnictwo/psr-2010/powszechny-spis-rolny-2010-uzytkowanie-gruntow,6,1.html\#

Górz, B. (2003). Społeczeństwo i gospodarka Podhala w okresie transformacji. Kraków: Wydawnictwo Akademii Pedagogicznej.

Górz, B. (2006). Rolnictwo Polski południowo-wschodniej (uwarunkowania rozwoju i współczesny stan). W: B. Głębocki (red.), Rolnictwo Polski u progu XXI wieku. Poznań: Bogucki Wydawnictwo Naukowe, 311-356.

Górz, B., Uliszak, R. (2014). Teraźniejszość i przyszłość małych gospodarstw. Rozwój Regionalny i Polityka Regionalna, 26, 57-71.

Hryniewicz, J.T. (2000). Endo i egzogeniczne czynniki rozwoju gospodarczego gmin i regionów. Studia Regionalne i Lokalne, 2(2), 53-77.

Jakóbik, K. (red.). (2015). Rolnictwo w województwie małopolskim w 2014 r. Kraków: Urząd Statystyczny w Krakowie.

Kopeć, B. (1964). Metoda wskaźników i dat granicznych w określaniu systemu gospodarczego. Zagadnienia Ekonomiki Rolnej, 2, 3-20.

Leśniak, M. (2009). Emigracja zarobkowa - rodzina polska w nowej rzeczywistości Społeczno-Wychowawczej. Pedagogika Rodziny, 1, 127-134.

Zegar, J.S. (2012). Rola drobnych gospodarstw rolnych w procesie społecznie zrównoważonego rozwoju obszarów wiejskich. Problemy Drobnych Gospodarstw Rolnych, 1, 129-148.

Bronisław Górz, prof. dr hab., profesor zwyczajny w Instytucie Nauk Humanistyczno-CSpołecznych i Turystyki PPWSZ w Nowym Targu, kierunek turystyka i rekreacja. Problematyka badawcza autora dotyczy przemiany na obszarach wiejskich Polski, wielofunkcyjny rozwój małopolskich wsi, rola turystyki w przekształcaniu gospodarki wsi karpackich, gospodarka i społeczeństwo Podhala, transformacje społeczno-gospodarcze na obszarach wiejskich w krajach Europy Środkowo-Wschodniej po roku 1990.

Bronisław Górz, professor in the Institute of Humanities, Social Sciences and Tourism at the PPWSZ in Nowy Targ. Research issues of the author refer to changes in the Polish rural areas, multifunctional development of rural areas in Małopolska, the role of tourism in the Carpathian village transformation of the economy, the economy and society of Podhale, socio-economic transformations in rural areas in the countries of Central and Eastern Europe after 1990.

\section{Adres/Address:}

Podhalańska Państwowa Wyższa Szkoła Zawodowa

Instytut Nauk Humanistyczno-Społecznych i Turystyki

ul. Kokoszków 71

34-400 Nowy Targ, Polska

e-mail: brogor@o2.pl 
Agnieszka Gil, mgr, absolwentka studiów z zakresu geografii społeczno-ekonomicznej Uniwersytetu Pedagogicznego im. KEN w Krakowie. Asystent w Instytucie Geografii (Zakład Geografii Społeczno-Ekonomicznej). Zainteresowania badawcze autorki dotyczą geografii obszarów wiejskich, rozwoju lokalnego i regionalnego na obszarze Polski.

Agnieszka Gil, has graduated from the Pedagogical University of Cracow with an MA degree in geography. PhD student in the Institute of Geography of the Pedagogical University of Cracow. Her research interests relate to geography of rural areas, local and regional development in Poland. Uniwersytet Pedagogiczny im. Komisji Edukacji Narodowej w Krakowie

\section{Adres/Address:}

Uniwersytet Pedagogiczny im. Komisji Edukacji Narodowej w Krakowie

Instytut Geografii

ul. Podchorążych 2

30-084 Kraków, Polska

e-mail: agnieszkagil@up.krakow.pl

Marcin Semczuk, dr, adiunkt w Katedrze Gospodarki Regionalnego Uniwersytetu Ekonomicznego w Krakowie. Zainteresowania badawcze autora skupiają się wokół problematyki rozwoju obszarów wiejskich, zwłaszcza tych mających charakter peryferyjny, polityki regionalnej i lokalnej oraz zróżnicowania dostępu do szkolnictwa podstawowego na obszarach wiejskich. Jest autorem (lub współautorem) ponad dwudziestu artykułów naukowych publikowanych w Polsce oraz w czasopismach zagranicznych. Od 2017 roku jest członkiem Polskiego Towarzystwa Geopolitycznego, jako członek zarządu, a od 2018 roku jest również członkiem Polskiego Towarzystwa Geograficznego.

Marcin Semczuk, doctor of Earth Sciences, assistant professor in the Department of Regional Economy at the Cracow University of Economics. His research focuses on rural development issues, especially issues concerning peripheral rural areas, regional and local politics and diversification of access to primary education in rural areas. Recent work explores to what extent the peripherality of the location determines the opportunities for economic development. The author (or co-author) of more than twenty reviewed research papers published in Poland and abroad. Since 2017 he has been a member of the Polish Geopolitical Society of which he is a member of the board, and since 2018 he has been a member of the Polish Geographical Society.

\section{Adres/Address:}

Uniwersytet Ekonomiczny w Krakowie

Katedra Gospodarki Regionalnej

ul. ul. Rakowicka 27

31-510 Kraków, Polska

e-mail: semczukm@uek.krakow.pl 